\section{Nuisance to Invasive Ornamentals: Proceedings from the ASHS Invasive Plants Research Group 2020 Workshop}

\author{
Michael A. Schnelle ${ }^{1}$ and Lyn A. Gettys ${ }^{2}$
}

AdDITIONAL INDEX wORDs. aggressive plants, grasses, herbaceous ornamentals, invasion ecology, weed control, woody ornamentals

$\mathrm{W}$ holesalers, retailers, and end consumers should produce, sell, or grow environmentally appropriate plants in response to enhanced concerns among those seeking to protect and preserve the environment. Voluntarily acknowledging and practicing environmental stewardship, by reducing weedy to invasive plant spread, behooves all involved. The ornamentals industry is a key source of nonnative species escaping from cultivation (Lehan et al., 2013; Pysek et al., 2011; Reichard and White, 2001; van Kleunen et al., 2018), and it is thought that the ornamentals industry has introduced in excess of 50,000 species to the United States for the nursery and landscape market (Gordon and Gantz, 2008). However, based on a survey encompassing 6885 species grown by mid-Atlantic U.S. nurseries, only $4 \%$ were deemed invasive in the region served by these nurseries [Connecticut, Delaware, Maryland, New Jersey, New York, Pennsylvania, Virginia, Washington, District of Columbia, and West Virginia (Coombs et al., 2020)]. In addition to the nursery industry, nonnative plants have been introduced to the

Received for publication 30 Dec. 2020. Accepted for publication 10 Mar. 2021.

Published online 11 May 2021

${ }^{1}$ Department of Horticulture \& Landscape Architecture, Oklahoma State University, 358 Agricultural Hall, Stillwater, OK 74078

${ }^{2}$ University of Florida IFAS Fort Lauderdale Research and Education Center, 3205 College Avenue, Davie, FL 33314

This paper is an introduction to a series of papers from the workshop titled "Progress in Identification and Control of Weedy to Invasive Plants both Domestic and Abroad" that was presented during the 2020 ASHS Annual Conference, which was held virtually 10-13 Aug. 2020.

M.A.S. is the corresponding author. E-mail: mike.schnelle@okstate.edu.

This is an open access article distributed under the CC BY-NC-ND license (https://creativecommons. org/licenses/by-nc-nd/4.0/).

https://doi.org/10.21273/HORTTECH04787-20
United States via botanical gardens and arboreta, nurseries, garden club and horticultural society seed exchanges, and the seed trade industry to meet medicinal and culinary demands, interest in personal aquaria and water gardens, and soil erosion mitigation needs (Reichard and White, 2001).

The global economic and ecological ramifications of invasive plants are thoroughly documented and have been summarized elsewhere by a number of researchers [e.g., Kettenring and Adams (2011), Pysek et al. (2012), Weidlich et al. (2020), and many others]. Invasive plants inflict harm in a number of ways, including reducing crop yields and pasture forage (Pimentel, 2009), interfering with native plant populations, and disrupting and altering hydrological processes (Pysek et al., 2012; Weidlich et al., 2020). Furthermore, invasive plants negatively impact native fauna (Fletcher et al., 2019) and have dire financial consequences. For example, invasive species (including plants, pathogens, and animals) cause damage valued at more than $\$ 1.4$ trillion globally, and economic damage from invasive plants in the United States alone is estimated to range from $\$ 40$ billion to \$120 billion annually (City of Portland Oregon, Bureau of Environmental Services, 2021; Diagne et al., 2020a, 2020b; Hanley and Roberts, 2019; Pimentel et al., 2000, 2001, 2005).

Invasive plants are often more competitive than native species for a number of reasons, including enhanced resource uptake and use efficiency (Byun et al., 2018; Holzmueller and Jose, 2009). Rapid growth and reproduction rates of invasive species are often aggressive, resulting in dense monocultures that are not typically found in their native range (Hierro et al., 2005). Nonnative species may alter their invaded environment by producing allelochemicals that hinder native plant growth and vigor, lowering soil $\mathrm{pH}$ and altering nutrient cycling within the native stands (Bias et al., 2003; Callaway and Aschehoug, 2000). Phenotypic plasticity in some invasive plants enables them to tolerate a wide spectrum of environmental conditions, which expands potential sites they may invade (Richards et al., 2006); for example, fire can promote some invasive species, whereas some invasive species can promote fire (Brooks et al., 2004). Species growing outside their native range are not subject to attack by the coevolved specialist predators that keep their growth in check in their native range (i.e., enemy release hypothesis), and invasive species may be unpalatable, ignored, or subject to minimal damage from generalist enemies in their expanded territory (Keane and Crawley, 2002).

In addition to these factors, management efforts can affect the survival and establishment of invasive species. For example, some nonnative species mimic native plants, which allows them to escape detection and grow unchallenged as a result of their resemblance to desirable vegetation (Barrett, 1983; Marble and Brown, 2021). At least 263 species are reportedly resistant to herbicides, thus allowing them to survive and multiply unchecked despite attempted control measures (Heap, 2021). Current and future invasions are bolstered as a result of commercial research and development operations that are shifting away from agrichemical development and focusing on the development of genetically modified crops (Phillips, 2020).

Experts' opinions or definitions as to what constitutes an invasive plant vary widely. Mooney and Cleland (2001) described invasive species as those that are introduced to a novel environment with negative ecological, economic, or social impacts. Similarly, Reichard and White (2001) defined an invasive plant as one that has (or is likely to) spread into native flora and managed plant systems, developed self-sustaining populations, and become dominant or disruptive (or both) in those systems. It has long been assumed that most aggressive plants are invasive species and are, by definition, nonnative, because they have invaded a habitat to which they are not native. However, it is becoming clear that native species are not always "well-behaved," and that some indigenous species can be as destructive and damaging as nonnative 
species. For example, a number of mostly recent reports (e.g., Anderson, 2019; Anderson et al., 2021; Gettys, 2019; Marble, 2018; Reichard and White, 2001; Robertson et al., 2020; Ruter, 2019; Schnelle, 2019; Simberloff et al., 2012) acknowledge that native plant species can also exhibit behavior that ranges from weedy to invasive in nature and in cultivated settings. Also, there are conflicting opinions on how to categorize native plants that are nuisances vs. those that are actually invasive-in other words, do they have the potential simply to be an inconvenience or annoyance, or are they displacing other native flora and/or fauna and disrupting ecological processes? Given these diverse points of view, an impasse exists in reaching a consensus on what constitutes an "invasive" plant and how to mitigate invasions. A variety of terms have been proposed to describe plants with aggressive growth regardless of nativity (e.g., Colautti and Richardson, 2009; Pysek et al., 2004; Richardson et al., 2008; Warren, 2007). Iannone et al. (2020) suggest seven terms (native, nonnative, introduced, established, invasive, nuisance, and range change) that can be used to describe any species; these terms are intuitive and easily understood, which should increase understanding and thus promote behavioral changes that support efforts to mitigate the negative impacts of invasive species.

Regardless of semantics, various plans have been proposed to discourage or "police" introductions of harmful nonnative species. For example, Barbier et al. (2013) suggested that an annual license fee paid by the industry would reduce the risk of potentially dangerous introductions while raising funds for research, screening imported species, and promoting the education and eradication of existing invasive populations. In contrast, Cordeiro et al. (2020) proposed targeting consumers by providing them with information about invasive plants, which could reduce or prevent introductions and bolster support for control interventions.

The Invasive Plants Research Professional Interest Group of the American Society for Horticultural Science (ASHS) developed and executed a workshop at the 2020 ASHS annual conference to explore, debate, and mitigate this widespread dilemma of plants with invasive tendencies. The objective of this workshop, titled "Progress in Identification and Control of Weedy to Invasive Plants both Domestic and Abroad," was to highlight species known to be occasionally problematic and to discuss prudent corrective measures that can be taken to reduce their negative effects on the environment. Given the controversy and ongoing debate among scientists regarding invasive plants, coordinators M.A. Schnelle and L.A. Gettys invited speakers to describe troublesome species and practical approaches to mitigating their ecological and financial ramifications. Schnelle provided introductory remarks and then proceeded to deliver the first presentation, "Native Species that Merit Active Surveillance." Schnelle highlighted a number of herbaceous and woody ornamentals, all native to the United States, that reportedly can be nuisances or even invasive in nature, depending upon local environmental conditions and cultural practices. N.O. Anderson spoke about invasive reed canarygrass (Phalaris arundinacea) and discussed recent research findings that the species is actually native, although previously deemed exotic. Given that reed canarygrass is often indigenous to the midwestern region of the United States, this revelation affects land managers' and legislators' actions and decisions going forward. S.B. Wilson followed with a review of heavenly bamboo (Nandina domestica), which has escaped cultivation in eight southeastern U.S. states. She provided viable alternatives, including lowor nonfruiting cultivars, that can be substituted for more aggressive heavenly bamboo taxa. Chemical control options for two introduced ornamentals, lesser celandine (Ficaria verna) and dwarf fountain grass (Pennisetum alopecuroides), were outlined by the next speaker, $M$. Taylor. The last presentation was delivered by S.C. Marble, who outlined characteristics that can be used to distinguish a collection of invasive plants in Florida from native plants with similar appearances. Marble provided not only identification tips, but also control strategies for plants that are deemed invasive. The workshop concluded with an open discussion and roundtable, during which speakers fielded diverse questions from workshop participants; topics included chemical and cultural control measures, breeding efforts, and strategies that can be used to educate academics, green industry leaders and, ultimately, end-user clientele on combating weedy to invasive plants regardless of their origins. This workshop provided attendees with timely and practical information on basic principles, tenets, and management practices that could be tailored to suit their specific needs and respective geographic region.

\section{Literature cited}

Anderson, N.O. 2019. Throwing out the bathwater but keeping the baby: Lessons learned from purple loosestrife and reed canarygrass. HortTechnology 29:539-548, doi: 10.21273/HORTTECH04307-19.

Anderson, N.O., A.G. Smith, A.K. Noyszewski, E. Ito, D. Dalbotten, and H. Pellerin. 2021. Management and control issues for native, invasive species (reed canarygrass): Evaluating philosophical, management and legislative issues. HortTechnology 31:354-366.

Barbier, E.B., D. Knowler, J. Gwatipedza, S.A. Reichard, and A.R. Hodges. 2013. Implementing policies to control invasive plant species. Bioscience 63(2):132-138, doi: 10.1525/bio.2013.63.2.9.

Barrett, S.C.H. 1983. Crop mimicry in weeds. Econ. Bot. 37:255-282, doi: $10.1007 / \mathrm{BF} 02858881$.

Bias, H.P., R. Vepachedu, S. Gilroy, R.M. Callaway, and J.M. Vivanco. 2003. Allelopathy and exotic plant invasion: From molecules and genes to species interactions. Science 301(5638):1377-1380, doi: 10.1126/science.1083245.

Brooks, M., C.M. D'antonio, D.M. Richardson, J.B. Grace, J.E. Keeley, J.M. DiTomaso, R.J. Hobbs, M. Pellant, and D. Pyke. 2004. Effects of invasive alien plants on fire regimes. Bioscience 54(7):677688, doi: 10.1641/0006-3568(2004)054 [0677:EOIAPO]2.0.CO;2.

Byun, C., S. de Blois, and J. Brisson. 2018. Management of invasive plants through ecological resistance. Biol. Invas. 20:13-27, doi: 10.1007/s10530-017-1529-7.

Callaway, R.M. and E.T. Aschehoug. 2000. Invasive plants versus their new and old neighbors: A mechanism for exotic invasion. Science 290(5491):521-523, doi: 10.1126 /science.290.5491.521.

City of Portland Oregon, Bureau of Environmental Services. 2021. The problem with invasive plants. 24 Feb. 2021. <https://www.portlandoregon. gov/bes/article/330681 >.

Coombs, G., D. Gilchrist, and P. Watson. 2020. An assessment of the native and invasive horticultural plants sold in the mid-Atlantic region. Native Plants J. 21(1):74-82. 
Cordeiro, B., H. Marchante, P. Castro, and E. Marchante. 2020. Does public awareness about invasive plants pay off? An analysis of knowledge and perceptions of environmentally aware citizens in Portugal. Biol. Invas. 22:2267-2281, doi: 10.1007/ s10530-020-02247-z.

Colautti, R.I. and M. Richardson. 2009 Subjectivity and flexibility in invasion terminology: Too much of a good thing? Biol. Invas. 11:1225-1229, doi: 10.1007/ s10530-008-9333-z.

Diagne, C., J.A. Carford, F. Essl, M.A. Nunez, and F. Courchamp. 2020a. What are the economic costs of biological invasions? A complex topic requiring international and interdisciplinary expertise. NeoBiota 63:2537, doi: $10.3897 /$ neobiota.63.55260.

Diagne, C., B. Leroy, R.E. Gozlan, A.-C. Vaissiere, C. Assailly, L. Nuninger, D. Roiz, F. Jourdain, I. Jaric, and F. Courchamp. 2020b. InvaCost, a public database of the economic costs of biological invasions worldwide. Sci. Data 7:277, doi: 10.1038/s41597-020-00586-z.

Fletcher, R.A., R.K. Brooks, V.T. Lakoba, G. Sharma, A.R. Heminger, C.C. Dickinson, and J.N. Barney. 2019. Invasive plants negatively impact native, but not exotic, animals. Glob. Change Biol. 25(11):3694-3705, doi: $10.1111 / \mathrm{gcb} .14752$.

Gettys, L.A. 2019. Breaking bad: Native aquatic plants gone rogue and the invasive species that inspire them. HortTechnology 29:559-566, doi: 10.21273/HORTTECH 04333-19.

Gordon, D.R and C.A. Gantz. 2008. Screening new plant introductions for potential invasiveness: A test of impacts for the United States. Conserv. Lett. 1(5):227-235, doi: 10.1111/j.1755-263X.2008.00032.x.

Hanley, N. and M. Roberts. 2019. The economic benefits of invasive species management. People Nat. 1(2):124-137, doi: $10.1002 /$ pan3.31.

Heap, I. 2021. The international herbicide-resistant weed database. 16 Feb. 2021. <www.weedscience.org/Home. $\operatorname{aspx}>$.

Hierro, J.L., J.L. Maron, and R.M. Callaway. 2005. A biogeographical approach to plant invasions: The importance of studying exotics in their introduced and native range. J. Ecol. 93(1):5-15, doi: 10.1111/j.0022-0477.2004.00953.x.

Holzmueller, E.J. and S. Jose. 2009. Invasive plant conundrum: What makes the aliens so successful? J. Trop. Agr. 47(1-2): 18-29.

Iannone, B.V., III, S. Carnevale, M.B. Main, J.E. Hill, J.B. McConnell, S.A. Johnson, S.F.
Enloe, M. Andreu, E.C. Bell, J.P. Cuda, and S.M. Baker. 2020. Invasive species terminology: Standardizing for stakeholder education. J. Ext. 58(3):a3. <https://archives.joe.org/ joe/2020june/a3.php $>$.

Keane, R.M. and M.J. Crawley. 2002. Exotic plant invasions and the enemy release hypothesis. Trends Ecol. Evol. 17(4): 164-170, doi: 10.1016/S0169-5347(02) 02499-0.

Kettenring, K.M. and C.R. Adams. 2011. Lessons learned from invasive plant control experiments: A systematic review and metaanalysis. J. Appl. Ecol. 48(4):970-979, doi: 10.1111/j.1365-2664.2011.01979.x.

Lehan, N.E., J.R. Murphy, L.P. Thorburn, and B.A. Bradley. 2013. Accidental introductions are an important source of invasive plants in the continental United States. Amer. J. Bot. 100(7):1287-1293, doi: 10.3732/ajb.1300061.

Marble, S.C. 2018. Native weedy pests of the deep south. HortScience 53:1244-1249, doi: 10.21273/HORTSCII3112-18.

Marble, S.C. and S.H. Brown 2021. Invasive plants with native lookalikes: How mistaken identities can lead to more significant plant invasions and delay management. HortTechnology 31:385-394.

Mooney, H.A. and E.E. Cleland. 2001. The evolutionary impact of invasive species. Proc. Natl. Acad. Sci. USA 98(10):54465451, doi: 10.1073/pnas.091093398.

Phillips, M.W.A. 2020. Agrochemical industry development, trends in R\&D and the impact of regulation. Pest Mgt. Sci. 76(10): 3348-3356, doi: 10.1002/ps.5728.

Pimentel, D. 2009. Invasive plants: Their role in species extinctions and economic losses to agriculture in the USA, p. 1-7. In: Inderjit (ed.). Management of invasive weeds. Springer, Dordrecht, the Netherlands, doi: 10.1007/978-1-4020-9202-2_1.

Pimentel, D., L. Lach, R. Zuniga, and D. Morrison. 2000. Environmental and economic costs of nonindigenous species in the United States. Bioscience 50(1):53-65, doi: $10.1641 / 0006-3568(2000) 050$ [0053:EAECON]2.3.CO;2.

Pimentel, D., S. McNair, J. Janecka, J. Wightman, C. Simmonds, C. O'Connell, E. Wong, L. Russel, J. Zern, T. Aquino, and T. Tsomondo. 2001. Economic and environmental threats of alien plant, animal, and microbe invasions. Agr. Ecosyst. Environ. 84(1):1-20, doi: 10.1016/ S0167-8809(00)00178-X.

Pimentel, D., R. Zuniga, and D. Morrison. 2005. Update on the environmental and economic costs associated with alieninvasive species in the United States. Ecol.
Econ. 52(3):273-288, doi: 10.1016/j. ecolecon.2004.10.002.

Pysek, P., V. Jorosik, P.E. Hulme, J. Pergl, M. Hejda, U. Schaffner, and M. Vila. 2012. A global assessment of invasive plant impacts on resident species, communities and ecosystems: The interaction of impact measures, invading species' traits and environment. Glob. Change Biol. 18(5):1725-1737, doi: 10.1111/ j.1365-2486.2011.02636.x.

Pysek, P., V. Jarosik, and J. Pergl. 2011. Alien plants introduced by different pathways differ in invasive success: Unintentional introductions as a threat to natural areas. PLoS One 6(9):e24890, doi: 10.1371/journal.pone.0024890.

Pysek, P., D.M. Richardson, M. Rejmanek, G.L. Webster, M.K. Williamson, and J. Kirschner. 2004. Alien plants in checklists and floras: Towards better communications between taxonomists and ecologists. Taxon 53(1):131-143, doi: 10.2307/4135498.

Reichard, S.A. and P. White. 2001. Horticulture as a pathway of invasive plant introductions in the United States. Bioscience 51(2):103-113, doi: 10.1641/0006-3568 (2001)051[0103:HAAPOI]2.0.CO;2.

Richards, C.L., O. Bossdorf, N.Z. Muth, J. Gurevitch, and M. Pigliucci. 2006. Jack of all trades, master of some? On the role of phenotypic plasticity in plant invasions. Ecol. Lett. 9(8):981-993, doi: 10.1111/ j.1461-0248.2006.00950.x.

Richardson, D.M., P. Pysek, D. Simberloff, M.G. Rejmanek, and A.D. Mader. 2008. Biological invasions: The widening debate: A response to Charles Warren. Prog. Hum. Geogr. 32(2):295-298, doi: $10.1177 / 0309132507088313$.

Robertson, P.A., A. Mill, A. Novoa, J.M. Jeschke, F. Essl, B. Gallardo, J. Geist, I. Jaric, X. Lambin, C. Musseau, J. Pergl, P. Pysek, W. Rabitsch, M. von Schmalensee, M. Shirley, D.L. Strayer, R.A. Stefansson, K. Smith, and O. Booy. 2020. A proposed unified framework to describe the management of biological invasions. Biol. Invas. 22:2633-2645, doi: 10.1007/ s10530-020-02298-2.

Ruter, J.M. 2019. Inducing sterility in carolina cherry laurel using gamma irradiation. HortTechnology 29:535-538, doi: 10.21273/HORTTECH04289-19.

Schnelle, M.A. 2019. Native woody plants of the southern United Stateswithweedyorinvasive tendencies: A review of common offenders. HortTechnology 29:567-570, doi: 10.21273/HORTTECH04334-19.

Simberloff, D., L. Souza, M.A. Nunez, M.N. Barrios-Garcia, and W. Bunn. 2012. The natives are restless, but not often and 
mostly when disturbed. Ecology 93(3): 598-607, doi: 10.1890/11-1232.1.

van Kleunen, M., F. Essl, J. Pergl, G. Brundu, M. Carboni, S. Dullinger, R. Early, P. Gonzalez-Moreno, Q.J. Groom, P.E. Hulme, C. Kueffer, I. Kuhn, C. Magnus, N. Maurel, A. Navoa, M. Parepa, P. Pysek, H. Seebens, R. Tanner, T. Youza, L. Verbrugge, E. Weber, W. Dawson, H.
Kreft, P. Weigelt, M. Winter, G. Klonner, M.V. Talluto, and K. Dehnen-Schmutz. 2018. The changing role of ornamental horticulture in alien plant invasions. Biol. Rev. Camb. Philos. Soc. 93(3): 1421-1437, doi: 10.1111/brv.12402.

Warren, C.R. 2007. Perspectives on the 'alien' versus 'native' species debate: A critique of concepts, language and practice. Prog. Hum. Geogr. 31 (4):427-446, doi: $10.1177 / 0309132$ 507079499 .

Weidlich, E.W.A., F.G. Florido, T.B. Sorrini, and P.H.S. Brancalion. 2020. Controlling invasive plant species in ecological restoration: A global review. J. Appl. Ecol. 57(9):1806-1817, doi: $10.1111 / 1365-2664.13656$. 